\title{
Daffydd Fell, Government and Politics in Taiwan
}

London, Routledge, 278 pp.

\section{Gabriel Jonsson}

\section{(2) OpenEdition}

\section{Journals}

Electronic version

URL: http://journals.openedition.org/chinaperspectives/6065

DOI: $10.4000 /$ chinaperspectives.6065

ISSN: 1996-4617

\section{Publisher}

Centre d'étude français sur la Chine contemporaine

\section{Printed version}

Date of publication: 7 December 2012

Number of pages: 80-82

ISSN: 2070-3449

\section{Electronic reference}

Gabriel Jonsson, "Daffydd Fell, Government and Politics in Taiwan », China Perspectives [Online], 2012/4 | 2012, Online since 01 December 2012, connection on 21 September 2020. URL : http:// journals.openedition.org/chinaperspectives/6065; DOI : https://doi.org/10.4000/chinaperspectives. 6065

This text was automatically generated on 21 September 2020.

(c) All rights reserved 


\section{Daffydd Fell, Government and Politics in Taiwan}

London, Routledge, $278 \mathrm{pp}$.

\section{Gabriel Jonsson}

1 Government and Politics in Taiwan is a new textbook by Daffydd Fell, Senior Lecturer in Taiwan Studies at the School of Oriental and African Studies, University of London (research completed in April 2011). The author is "an experienced teacher and scholar" who has used numerous sources, including his own works from 2002-2011, carried out many interviews, and benefited from his long acquaintance with a country that, apart from its elections, attracts little reporting by the Western media.

2 Fell writes (p. 2) that "one of the motivations of this volume is to introduce modern Taiwanese politics from a comparative political science perspective and hopefully inspire readers to delve

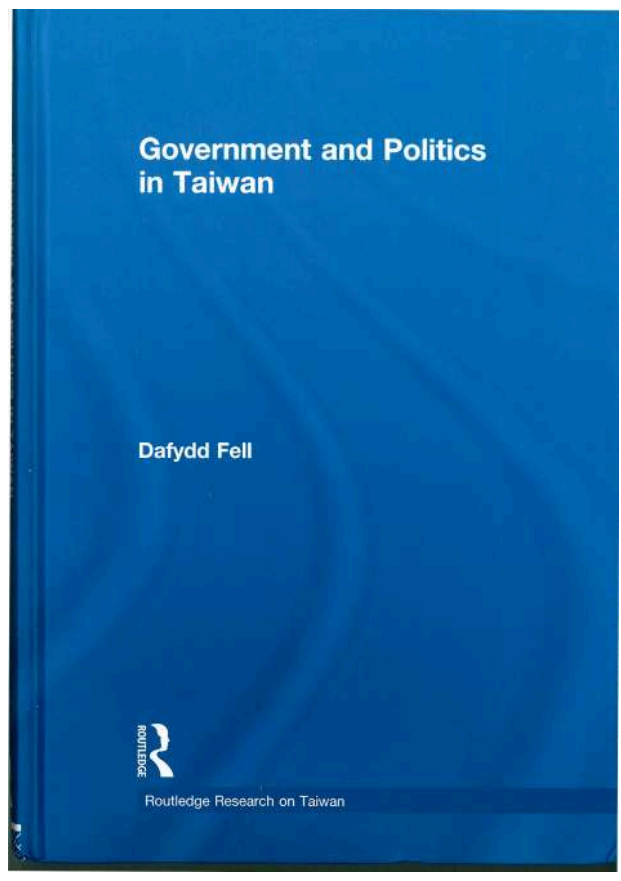
deeper into the subject." The introduction also records some basic data such as the holding of multi-party elections in 1989 and the first direct presidential elections in 1996 as well as the subsequent change of government in 2000 from the Kuomintang party (KMT) to the Democratic Progressive Party (DPP) and in 2008 back to the KMT. Notably, Fell also writes (p. 4): "Despite its democratic flaws, Taiwan is evidence that Western democracy can work in Chinese or other Confucian societies." The chapter ends, as all the others do, with discussion points and suggestions for further reading enhancing the study's value as a textbook. 
Chapter 2 explains how Taiwan was governed under martial law from 1949-1987, but it begins by discussing the political legacy of the Japanese colonial period (1895-1945). When Taiwan was subsequently ruled by the Republic of China (ROC), its rule went wrong quickly. The 19472.28 incident was the main backlash and is a long-standing controversial issue. The KMT brutally suppressed the protest instigated by the arrest of an illegal cigarette vendor after the Taiwanese retaliated against mainlanders. An estimated 10,000 people were killed, causing lasting tensions between the two groups. However, the KMT managed to recover and delivered political stability and economic success while the country was a one-party state. The authoritarian era has continued to affect politics through its impact on institutions, political parties, political issues, and the island's international status.

Chapter 3 reviews Taiwan's democratisation since the 1980s, attributed to KMT policies, pressure from the United States, and the "demonstration effect" from the fall of Ferdinand Marcos in the Philippines in 1986 and the downfall of communism in Eastern Europe. The Presbyterian Church and the student movement also contributed. In 1989, the formation of political parties was legalised. In 1990, a national conference on political reforms gave further impetus to the process that Taiwan-born President Lee Teng-hui (1988-2000) implemented successfully. When presidential elections were held in 1996, the non-governmental organisation Freedom House regarded Taiwan as a free country. Freedom House has carried out surveys since 1972 to rank countries on scales of political and civil rights ranging from not free, to partly free, to free. In 2000, Taiwan was even regarded as a model of democracy in Asia, but opinions are divided on how democracy has worked since.

Chapter 4 introduces Taiwan's government structure in its democratic era. The ROC Constitution from 1947 has remained in force, but a few revisions have been made. Whereas the KMT wished to maintain indirect presidential elections, the DPP wanted to implement direct elections that eventually became one of the constitutional revisions in the 1990s. Later, in 2005, single member districts were introduced, and the National Assembly was abolished and replaced by the Legislative Yuan. The number of legislators was halved from 225 to 113 and their terms extended from three to four years so that it would correspond with the President's term.

6 Chapter 5 looks at Taiwan's electoral politics. Elections have been held at some level during 19 of the 25 years that have passed since the DPP was set up in 1986. In 2000, DPP candidate Chen Shui-bian was elected president after a rebel left the KMT to run as an independent. However, the National Assembly was dominated by the KMT, undermining Chen's rule. The KMT won the 2008 elections, benefiting from the 2005 electoral reform. Fell points out that election campaigns are important in democracies and describes how election campaigns were pursued by actively using the media. Political issues became more important than ideology.

7 Chapter 6 introduces the main political parties that have dominated Taiwan politics since the 1980s; notably, analysing political parties from a left-right framework is not very fruitful. The review includes organisational structure, ideologies, party image, leadership, candidate selection methods and inner party balances of power. There was a struggle for power within the KMT after the death of Chiang Ching-kuo between supporters and opponents of successor Lee Teng-hui. In 2008, Tsai Ing-wen became new DPP leader after the party lost the presidential election. Since 2005, a two-party system 
has been in force. The success and failure of the smaller challenger parties as well as the changing party system is also included.

Chapter 7 considers how political patterns have changed at local levels. Whereas national level elections were fully introduced only in the 1990s, local elections have been held since the late 1940s. The chapter focuses on the KMT local factional relationships after the lifting of martial law. Struggle for power within the party was intense in the late 1980s and early 1990s. Yet, in elections the KMT remained, thanks to its organisational strength, the main political force on the local level in contrast to the national level.

Chapter 8 focuses on the competing nation-building projects, i.e., reunification versus independence, promoted by political elites before and after democratisation and based on the legacy of Japanese imperialism, Chinese nationalism, and Taiwanese nationalism. National identity is the dominant issue in the study of Taiwanese politics since the 1990s. During the 1990s, the DPP struggled for membership in the UN, from which Taiwan had been expelled in 1971. In contrast, the KMT aimed to diversify external relations. An opinion survey from 2010 shows that since 2001 there has been a majority in favour of maintaining the status quo, whereas the number of proponents for unification has fallen significantly since 1993. In 2010, most interviewees regarded themselves as Taiwanese or both Chinese and Taiwanese, whereas only a tiny majority saw themselves as only Chinese. At that time, the one to two million people who lived and worked in mainland China were largely absent from the surveys on identity. The large number of Taiwanese living there raised such questions as whether they would be influenced by growing Chinese nationalism or would promote their sense of distinct Taiwanese identities as a consequence of their direct daily contacts with Chinese citizens.

Chapter 9 reviews Taiwan's external relations under martial law and the Cold War international system and how they have developed after political liberalisation. Taiwan fulfils the requirements for establishing a state by having a permanent population, a defined territory, and working government with agencies capable of entering into contact with other countries. In 1971, Taiwan was recognised by 68 countries against 53 countries recognising China. Today the island is recognised by only 23 countries but maintains non-official relations with most UN member states. There were minimal contacts between Taiwan and China from 1949-1987, whereas subsequent developments were characterised by economic convergence but political divergence. The 1995-96 missile crisis aimed to turn Taiwanese public opinion against Lee Teng-hui, whom China called "a traitor and sinner who sought to split the mainland." Since the KMT and the DPP took a firm stand against China, the Chinese threats helped Lee Teng-hui to get re-elected.

Chapter 10 considers the impact and strategies of the main social movements. Whereas the KMT suppressed associational life under martial law, civil society blossomed after 1987: the number of civil organisations grew from about 6,000 in 1987 to 34,171 in 2009. By challenging the KMT, they strengthened democracy. Politics in Taiwan has always been dominated by men, but women's organisations were established from 1987 onwards. The Equal Employment Law was enacted in 2001, and Annette Lu served as vice-president from 2000 to 2008 . The labour movement, the environmental protection movement, and the student movement are also included in the analysis. Although not a 
mass movement, environmental activists contributed to the delay of the construction of the island's fourth nuclear reactor.

Chapter 11 investigates whether democracy in Taiwan is working or not by looking at social welfare systems and political corruption. The KMT pursued welfare programs to benefit its supporters. Social welfare became more important during the political transition beginning in 1987. The introduction of Universal National Health Insurance in 1995 was a great success. Although Taiwan is usually regarded as a country that has successfully combined high economic growth and income equality, the Gini coefficient grew in the 1990s and 2000s. Democratisation and liberalisation of the media have made political corruption an important issue since 1987. During the years 1949-1987, corruption was pervasive, but also from 1992 to 1997 the KMT was regarded as more corrupt than the DPP. Although the DPP pursued an anti-corruption campaign in 2000-2004 to prevent vote buying, corruption remained a contested political issue that contributed to the party's defeat in the 2008 presidential election. Indeed, President Chen Shui-bian himself was arrested on charges of corruption immediately after he resigned, and in 2010 was sentenced to 17-and-a-half-years in jail for having taken bribes. Since welfare has expanded and political corruption is not accepted, Fell concludes that democracy is working in Taiwan.

Chapter 12 focuses on political developments since 2000. The election of Chen Shui-bian as president in 2000 meant not only the end of KMT rule in Taiwan but also the first shift of power in a Chinese nation. Although his power was undermined by the party's lack of parliamentary majority, social welfare expanded and labour rights improved. The country's international status weakened, but de facto independence was institutionalised. Lee Teng-hui had to resign as party leader after the KMT's defeat. President Chen Shui-bian was barely re-elected in 2004. The KMT was strengthened by the election of Ma Ying-jeou as new party leader in 2005. In contrast, the DPP was weakened during its second term in office by a more extreme position on the national identity issue, few political accomplishments, worsening of the economy, and tense cross-Strait relations. The most important changes since 2008 took place in foreign relations with the acceptance of tourists from China, direct flights to the mainland, Chinese investments, and in 2010 the signing of the comprehensive Economic Cooperation Frame-work Agreement. That Taiwan has not lost any of its allies is a success. On the other hand, international NGOs have criticised the KMT for intervening against the media.

Chapter 13 considers "the remarkable political miracles Taiwan has achieved over the last few decades" and the challenges democracy is facing. Democracy has been achieved by reform of existing institutions: the KMT has shown adaptability. There have been two shifts of power, active election campaigns, and institutionalisation of political parties. Thanks to the active civil society, transparency in politics has improved since 1987. Democracy has created a positive image of Taiwan in the global community. Since Fell convincingly argues for his positive evaluation of the state of democracy in Taiwan, it is hard to argue against him. However, considering that the working of democracy in any society is affected by indigenous culture, Fell should at least briefly have elaborated somewhat on the relationship between democracy and Confucianism here. Only time will tell whether there will be resolution to the challenges enumerated in terms of constitutional reforms to the political and electoral 
system, a strengthened and diversified political society, removal of authoritarian era legacies, and revival of political consensus.

Altogether, Fell successfully fulfils the objective stated on p. 2 and should inspire any reader to follow more closely how democracy in Taiwan and the national identity issue will develop. A few references to South Korea are made, and it is my impression from the book that politics in Taiwan have worked more smoothly. The most striking differences are that Taiwan allows re-election of the president and that virtually the same parties have taken part in politics since 1986, while in South Korea many new parties were formed with adverse impact on politics. Politics also seem to be less centred on personality and more on issues. Finally, the regionalism that is a divisive factor in Korean politics is no longer as significant in Taiwan as it was during the martial law era, since the old generations of mainlanders have died out and have been replaced by native Taiwanese, reducing tensions.

In brief, the book is indispensable reading for anyone who aims to understand Taiwanese politics, but readability would have been enhanced if a chronology of major events had been recorded in an appendix. All names in the text should have been consistently introduced briefly in the text and recorded in an appendix. A map of Taiwan should also have been added.

\section{AUTHOR}

\section{GABRIEL JONSSON}

Associate Professor in Korean Studies at Stockholm University (gabriel.jonsson@orient.su.se). 